\title{
Tobacco mosaic virus Detected in Vegetatively Propagated Petunia Hybrids 'Surfinia'
}

\author{
Bong Nam Chung*, Jeong Soo Kim, Jeom Deog Cho, Seung Ryong Cheong and Myeong II Jeong \\ Horticultural Environment Division, National Horticultural Research Institute, RDA, Suwon 440-310, Korea
}

(Received on January 6, 2007; Accepted on February 13, 2007)

Introduction of vegetatively propagated Petunia hybrids since 1992 led to increasing virus infections of propagation material. Petunia hybrid 'Surfinia' cultivated for pot-plant showed yellowing symptom along with stunt. Flowers were smaller in size and showed color-break symptom. Tobacco mosaic virus (TMV-pet) was isolated from the diseased petunia. Healthy petunia plants inoculated with TMV-pet induced mottle on leaves and color-break on flowers, and plants were stunted. Nucleotide sequences of coat protein gene amplified from RNA prepared from Nicotiana tabacum cv. Samsun infected with TMV-pet were determined (GenBank accession no. DQ981481). It showed $99.0 \%$ nucleotide sequence homology with TMV-potato3-2 (GenBank accession no. AF318215) isolated from potato showing yellow mosaic and stunt symptom, and with a TMV Korean strain (GenBank accession no. X68110). This is the first reported observation of TMV from vegetatively propagated petunia in Korea.

Keywords : Petunia, Tobacco mosaic virus

Petunia is an economically important ornamental which was usually propagated by seeds. Recently vegetatively propagated petunia hybrids were introduced into flowermarket. They are usually grown for pot-plants or for garden plants. 'Surfinia' has been called as representative on vegatatively propagated Petunia hybrids by growers in Korea.

Eleven viruses have been reported from petunia plant (Cohen and Sikron, 1999; Lesemann, 1996; Mavric et al., 1996). These include Potato virus Y, Tobacco mosaic virus, Tomato mosaic virus, Alfalfa mosaic virus, Cucumber mosaic virus, Petunia vein-clearing virus and Broad bean wilt I virus. They were often occurred in mixed infections (Lesemann, 1996).

Yellow symptom along with stunt has been occurred in commercial 'Surfinia' since 2003 in Korea. Those plants were collected from commercial green-house in Goyang, Gyeonggi Province (Fig. 1).

\footnotetext{
*Corresponding author.

Phone) +82-31-290-6236, FAX) +82-31-290-6259

E-mail) chbn7567@rda.go.kr
}

A pair of primer was designed on the basis of TMV isolate (GenBank accession no. NC001367). Forward primer was ATGTCTTACAGTATCACTACTCC and reverse primer was TCAAGTTGCAGGACCAGAGG Total RNA was extracted from a Nicotiana tabacum cv. Samsun systemically infected with TMV-pet by using RNeasy Plant Mini Kit (QIAGEN, Germany) according to manufacture's instruction. Complementary DNA (cDNA) synthesis was accomplished using a method described previously (Chung et al., 2005). PCR was conducted with the following cycles: denaturation at $94^{\circ} \mathrm{C}$ for $30 \mathrm{sec}$, primer annealing at $50^{\circ} \mathrm{C}$ for $1 \mathrm{~min}$ and extension at $72^{\circ} \mathrm{C}$ for $1 \mathrm{~min}$ for 40 cycles with a final extension at $72^{\circ} \mathrm{C}$ for $7 \mathrm{~min}$.

Eighteen indicator plants including Petunia hybrida cv. Violet were inoculated with crude sap of TMV-pet-infected $N$. tabacum cv. Samsun in $0.05 \mathrm{M}$ sodium phosphate buffer, $\mathrm{pH} 7.0$, and with TMV-Ul for comparison. Symptom was determined at 10 15 days after inoculation.

Crude sap of petunia infected with TMV-pet, negatively stained with $0.5 \%$ phosphotungustic acids $\mathrm{pH} 7.0$, was observed by using Carl Zeiss LEO 906 transmission electron microscope (TEM). Ultra structure of petunia infected with TMV-pet was observed with leaf thin sections prepared using a method described previously (Chung et al., 2004).

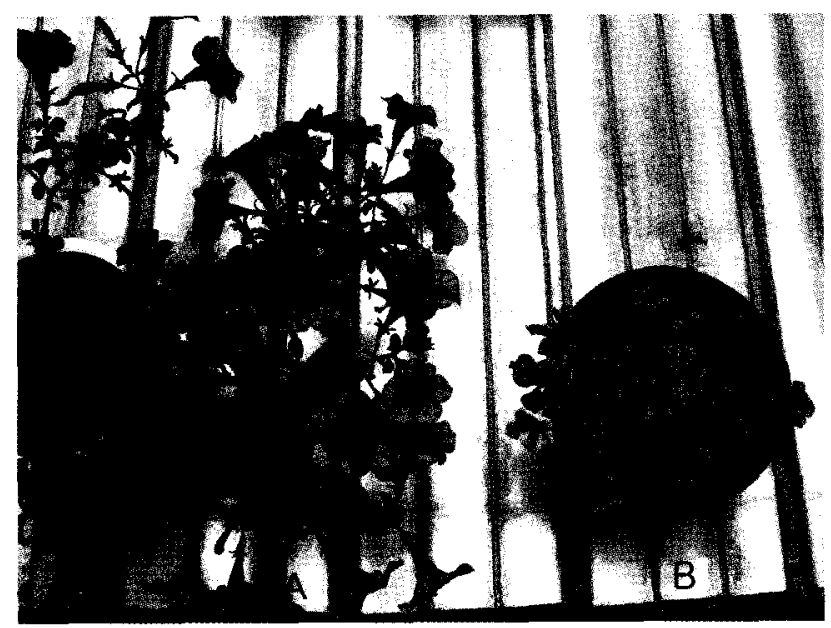

Fig. 1. Symptoms observed from petunia naturally infected with Tobacco mosaic virus. (A) Healthy petunia (B) Petunia infected with TMV-pet showing yellow, stunt and flower color-break. 


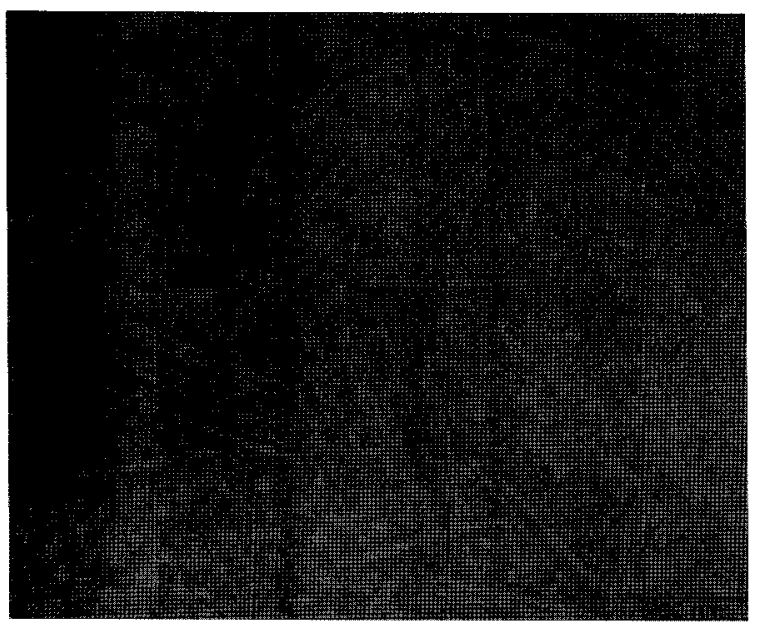

Fig. 2. Electron micrograph of TMV-pet prepared from negatively stained leaf-dip preparations of diseased petunia stained in $0.5 \%$ phosphotungustic acid. Bar indicates $200 \mathrm{~nm}$.

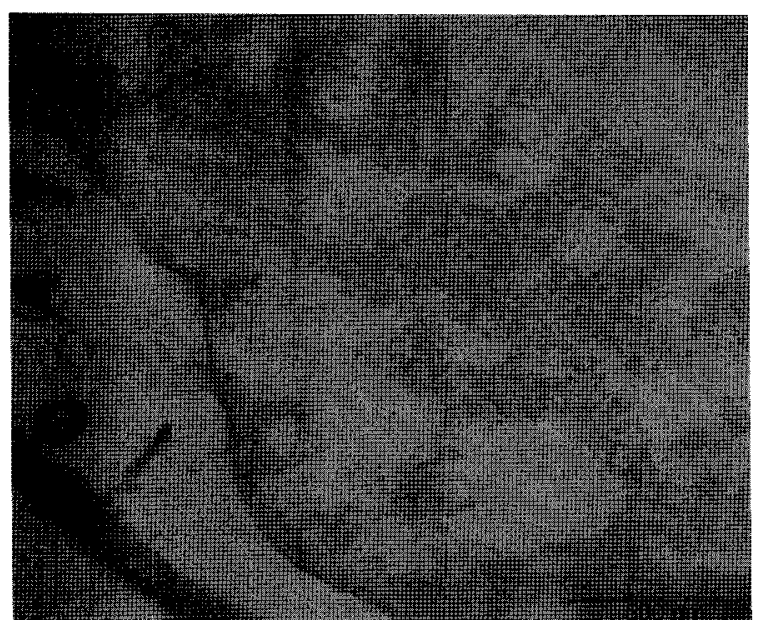

Fig. 3. Ultra structural observation of petunia infected with TMVpet. Rod shaped virions are shown in the cytoplasm. Bar indicates $500 \mathrm{~nm}$.

Around $300 \mathrm{~nm}$ length of rod shaped virus particles were observed from crude sap of diseased petunia (Fig. 2). Rodshaped virus particles were observed in the cytoplasm of diseased petunia (Fig. 3). Morphology and the length of the virus particles indicated that they belonged to tobamovirus.

TMV-pet systemically infected five Nicotiana species including $N$. clevelandii. TMV-pet developed local lesions on Cucumis sativus and Vigna unguiculata (Table 1), indicating that tobamovirus identified in the present study is not Tomato mosaic virus (ToMV). ToMV did not infect $C$. sativus and $V$. unguiculata (Huttinga and Rast, 1985). TMV-Ul showed similar responses to 18 indicator plants as TMV-pet. Healthy Petunia hybrid seedling cv. Violet revealed mottle with stunt and color break symptom by infection with TMV-pet (Fig. 4).
Table 1. Responses of indicator plants to TMV-pet

\begin{tabular}{|c|c|c|}
\hline \multirow{2}{*}{ Indicator plants } & \multicolumn{2}{|c|}{ Response } \\
\hline & TMV-pet & TMV-U1 \\
\hline Chenopodium quinoa & $\mathrm{CS} /-^{z}$ & $\mathrm{CS} /-$ \\
\hline C. amaranticolor & $\mathrm{NS} /-$ & $\mathrm{NS} /-$ \\
\hline Datura stramonium & NS/- & $\mathrm{NS} /-$ \\
\hline Vigna unguiculata & $\mathrm{NS} /-$ & $\mathrm{NS} /-$ \\
\hline Gomphrena globosa & $\mathrm{NS} /-$ & $\mathrm{NS} /-$ \\
\hline Physalis floridana & SM & SM \\
\hline Cucumis sativus & $\mathrm{NS} /-$ & $\mathrm{NS} /-$ \\
\hline Nicotiana clevelandii & SM & SM \\
\hline N. benthamiana & SM & SM \\
\hline N. rustica & SM & NS/SM \\
\hline N. occidentalis & SM & SM \\
\hline$N$. glutinosa & NS/- & NS/- \\
\hline N. tobacum cv. Samsun & SM & SM \\
\hline N. tobacum cv. White Burley & NS/- & NS/- \\
\hline N. tobacum cv. Samsun NN & NS/- & $\mathrm{NS} /-$ \\
\hline Petunia $\times$ hybrida $\mathrm{cv}$. Violet & SM & SM \\
\hline Petunia $\times$ hybrida cv. Carpet Red & SY & SY \\
\hline Petunia $\times$ hybrida $\mathrm{cv}$. Carpet White & SY & SY \\
\hline
\end{tabular}

${ }^{2}$ : symptom on inoculated leaf/symptom on upper uninoculated leaf. CS: Chlorotic spots; NS: Necrotic spots; SM: Systemic leaf mosaic; SY: Systemic yellowing; -: no infection.

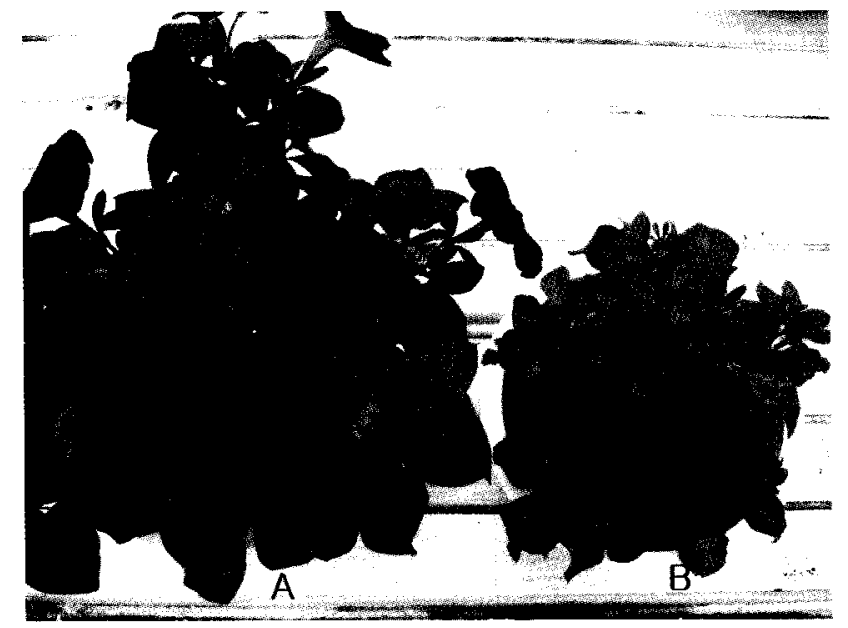

Fig. 4. Symptoms induced by mechanical inoculation of TMVpet. (A) Healthy petunia; (B) TMV-pet infected petunia showing stunt, flower color breaking and mottle on leaves.

Nucleotide sequence of coat protein (CP) gene of TMVpet showed $99.0 \%$ sequence homology with TMV-potato32 (GenBank accession no. AF318215) isolated from potato showing yellow mosaic and stunt symptom, and with a TMV Korean strain (GenBank accession no. X68110) (Table 2). Nucleotide sequences of CP gene of TMV-pet was submitted to the GenBank under the accession no. of 
Table 2. Nucleotide sequence homology (\%) of the CP gene of TMV-pet with other TMV isolates registered in GenBank

\begin{tabular}{lcccc}
\hline & AF165190 & X68110 & AY360447 & AF318215 \\
\hline TMV-pet & 99.0 & 99.0 & 99.0 & 99.0 \\
(DQ981481) & & & & \\
AF165190 & & 100.0 & 100.0 & 98.3 \\
X68110 & & & 100 & 98.3 \\
AY360447 & & & & 98.3 \\
\hline
\end{tabular}

DQ981481. Nucleotide sequences of the CP gene, biological assay, and the observation of virions by TEM proved that combined symptoms of yellowing, stunt and flower color break occurred from 'Surfinia' was caused by TMV-pet infection.

\section{References}

Cohen, J. and Sikron, N. 1999. Susceptibility of vegetatively propagated Petunia to Tobamovirus infection and its possible control. HortScience 34:292-293.

Chung, B. N., Lee, E. K. and Kim, H. R. 2004. First report on Poinsettia mosaic virus in Korea. Plant Pathol. J. 20:220-223.

Chung, B. N., Lim, J. H., Choi, S. Y., Kim, J. S. and Lee, E. J. 2005. Occurrence of Chrysanthemum stunt viroid in chrysanthemum in Korea. Plant Pathol. J. 21:377-382.

Huttinga, H. and Rast, A. Th. B. 1985. Tomato mosaic tobamovirus. Plant Viruses Online Descriptions and Lists from the VIDE Database.

Lesemann, D. E. 1996. Viruses recently detected in vegetatively propagated Petunia. Acta Hort. 432:88-94.

Mavric, I., Ravnikar, M. and Blatnik, A. 1996. Viruses infecting trailing Petunias in Slovenia. Phytoparasitica 24:328-329.

Zaitlin, M. 1984. Tobacco mosaic tobamovirus. Plant Viruses Online Descriptions and Lists from the VIDE Database. 